\title{
Polska, ale jaka?
}

Szli krzyczac: "Polska! Polska!”-wtem jednego razu

Chcąc krzyczeć zapomnieli na ustach wyrazu;

Pewni jednak, że Pan Bóg do synów się przyzna, Szli dalej krzyczac: „Boże! Ojczyzna! Ojczyzna!”.

Wtem Bóg z Mojżeszowego pokazat się krzaka, Spojrzat na te krzyczace i zapytat: "Jaka?”.

Juliusz Słowacki, Szli krzycząc: "Polska! Polska!”

MACIEJ ZAKRZEWSKI - dr nauk politycznych, pracownik Oddziałowego Biura Badań Historycznych Instytutu Pamięci Narodowej w Krakowie, adiunkt na Wydziale Historii i Dziedzictwa Kulturowego UPJP2, wiceprezes Ośrodka Myśli Politycznej, członek redakcji czasopisma „Folia Historica Cracoviensia”. Autor m.in. Wobronie konstytucji. Myśl polityczna Henry'ego St. Johna wicehrabiego Bolingbroke'a (2012). Obecnie przygotowuje monografię poświęconą myśli politycznej środowiska „Buntu Młodych” i „Polityki”. 
Spory o Rzeczpospolita. Przeglad wybranych dyskusji politycznych $i$ ustrojowych w ostatnim stuleciu, red. P. Gofron, A. Matuła, A. Paderewska, Kraków 2020, S. 12-23. DOI: http://dx.doi.org/10.15633/9788374388061.02

iewiele tekstów, w tym także tych o charakterze naukowym,
lepiej obrazuje naczelny problem polskiej myśli i praktyki politycznej ostatnich dwóch stuleci, jak powyższe słowa wieszcza. Od czasów zmierzchu Pierwszej Rzeczpospolitej trwa nieustannie debata, której dynamika przyćmiewana bywa jedynie przez erupcję czynów nadzwyczajnych, kiedy cel nadrzędny związany z odzyskaniem niepodległości wygłuszał, acz nie niwelował, wewnętrzne spory. To podczas trwania obrad tzw. Sejmu Wielkiego najgłośniej wybrzmiało pytanie o sens dotychczasowej, specyficznej „polskiej drogi” symbolizowanej przez wolność szlachecką, liberum veto, religię katolicką i władzę hetmańską. Konstytucja majowa była krytycznym przeglądem dotychczasowej tradycji, szczególnie w zakresie ustrojowym; była również testamentem upadającego państwa. Dyskusja nad samą konstytucją szybko wygasła na skutek dramatyzmu i szybkości późniejszych wydarzeń. Zawezwanie przez targowiczan rosyjskiej pomocy w celu obrony praw fundamentalnych Rzeczpospolitej, dyskredytowało krytyczny namysł nad symboliką aktu 3 maja. Ostatnim epigonem, acz odosobnionym, wrogo odnoszącym się do dorobku Sejmu Wielkiego, nota bene urodzonym 3 maja 1791 roku, był Henryk Rzewuski ${ }^{1}$. Jednak okoliczności upadku państwa w końcu wieku XVIII, a szczególnie

I Zob. szersze ujęcie I. Węgrzyn, Henryk Rzewuski wobec Rosji i idei stowiańskiej, w: Między realizmem a apostazja narodowa. Koncepcje prorosyjskie w polskiej myśli politycznej, red. M. Zakrzewski, Kraków 20 I 5, s. 75-98, H. Ślisz, Henryk Rzewuski. Życie i poglądy, Warszawa 1986. 
upadek powstania listopadowego, uświadomiły naczelny fâkt, że re restytucja Polski, nie będzie powrotem do czasów dawnych. Odrodzenie winno nieść ze sobą nową społeczną treść i skuteczne ustrojowe ramy.

Jednak siła sporu narastała z czasem, aby swój wyraźny obraz zyskać w chwili wybuchu powstania listopadowego. Pod sztandarami napoleońskimi w imię wyższej racji odnajdowali się obok księcia Józefa Poniatowskiego, polityczni radykałowie jak Józef Sułkowski. Patronat cesarza Francuzów wygaszał spory, na polu bitwy niesiono różne ideały, jednak hasło odzyskania utraconego państwa było naczelnym postulatem walki.

Okres pomiędzy kongresem wiedeńskim a powstaniem listopadowym to przede wszystkim walka z carską wizją Mikołaja I odnośnie do zasad konstytucji. Wzrastająca opozycja liberałów pod wodzą braci Niemojewskich walczyła o konstytucję i jej zachodnioeuropejską interpretację w duchu myśli Benjamina Constanta, a nie rosyjskiego autorytaryzmu. Równolegle wśród młodych rosło zwątpienie w skuteczność tej drogi i potrzeba było czynu nadzwyczajnego. Już w czasie powstania listopadowego zostały wyznaczone naczelne linie podziału. Nie tylko chodziło o kwestię taktyki, kiedy to kunktatorska strategia dawnych oficerów napoleońskich spotkała się ze zniecierpliwieniem bardziej stanowczo nastawionych podoficerów i mas warszawskich, ale przede wszystkim z całą siłą ujawnia się opcja, reprezentowana przez m.in. Maurycego Mochnackiego i Adama Gurowskiego, którzy widzą konieczność uzupełniania wojny o niepodległość rewolucją socjalną. O ile dla Mochnackiego rewolucja miała być środkiem do zmobilizowania społeczeństwa do walki, o tyle Gurowski prezentował już bardziej nowoczesne i bardziej korespondujące z ówczesnymi tendencjami lewicowymi w Europie podejście, podkreślające samoistność celów rewolucji socjalnej².

2 H. Głębocki, „Diabet Asmodeusz” w niebieskich binoklach i kraj przysztości. Hr. Adam Gurowski i Rosja, Kraków 201 2, s. I 45n.; M. Król, Konserwatyści i niepodlegtość. Studia nad polską myślą konserwatywną, Warszawa I98 5, s. 70-84. 
Napięcie odnośnie do charakterów i celów wojny zostało automatycznie przeniesione wraz powstańczymi weteranami na emigrację. Poczucie klęski potęgowało rozgoryczenie. To we Francji na nowo rozkwitła wolna myśl polityczna zdecydowanie formująca się wokół dwóch głównych ośrodków. Kierunek umiarkowany reprezentowało środowisko skupione wokół księcia Adama Jerzego Czartoryskiego. Podnosili oni hasło: Najpierw być, a potem Jak być. Stawiając nacisk na środki dyplomatyczne grupa Hotelu Lambert dostrzegała konieczność podnoszenia, wprawdzie ogólnikowych, postulatów przeprowadzenia uwłaszczenia ${ }^{3}$. Jednak w kontrze do zachowawców uformowało się Towarzystwo Demokratyczne Polskie, którego jednym z założycieli był m.in. Adam Gurowski. Tzw. Wielki Manifest TDP z I836 roku (znacznie bardziej umiarkowany w stosunku do manifestu z I832 roku), eksponował już radykalnie odmienną optykę niż zwolennicy księcia Adama Czartoryskiego. Jasno wskazywano nie tylko na problem związany z obcą polityczną dominacją, ale na problem wewnętrznej konstrukcji zasobów polskich. Pisano:

Wszystkie jej usiłowania o odzyskanie straconej niepodległości, okazują z jednej strony niemoc zamykającego się w sobie samym stanu i jego upór o zachowanie przywłaszczeń, z drugiej dowodzą niewygasłego w masach uczucia swobód i gotowości do walki, w miarę czynionych im obietnic i nadziei ${ }^{4}$.

Wyraźnie sprzęgnięto kwestie niepodległości z materialnym postulatem demokracji, odrzucano hasło Najpierw być, stawiając znak równości pomiędzy państwem i jego przyszłą treścią społeczną i polityczną. Z samego TDP wykształciła się bardziej skrajna grupa radykalizująca

3 Zob. szerz. M. Rysiewicz, Monarchia - lud-religia. Monarchizm konserwatywnych środowisk politycznych Wielkiej Emigracji w latach I83I-I848, Kraków 2015.

4 Manifest Towarzystwa Demokratycznego Polskiego (I 836), za: https://pl.wikisource.org/wiki/Manifest_Towarzystwa_Demokratycznego_Polskiego_ (1836) (29. 04. 2018). 
hasło demokracji w kierunku socjalistycznym, tj. Gromady Ludu Polskiego.

To napięcie, tak jasno wykrystalizowane w czasach tzw. Wielkiej Emigracji, towarzyszyło dziejom polskim nie tylko do I9I8 roku, ale trwało przez cały okres dwudziestolecia międzywojennego i pewne jego refleksy odbijają się na polskim życiu politycznym po dziś dzień. Pod koniec lat 90. XIX wieku w tradycji wyznaczonej przez TDP przeciwko postszlacheckiej konstrukcji narodu, swoje sztandary, opierające się już o nowoczesne ideologie polityczne, podnieśli z jednej strony socjaliści z PPS, z drugiej zaś - politycy nacjonalistyczni. W programie paryskim PPS pisano o Polsce rewolucyjnej, która może zebrać sity narodowe i kierować je ku zwycięstwu'. Carat w tym ujęciu stawał się przeciwnikiem w dwojakim znaczeniu: jako zawłaszczyciel państwa, ale także jako strażnik kapitalistycznego systemu własności. Walka miała się toczyć równolegle nie tylko o Polskę, ale i o socjalizm. Mimo, późniejszego i związanego z działalnością Piłsudskiego, mocniejszego zaakcentowania przez część polskich socjalistów kwestii narodowej, należy zawsze pamiętać o autentycznym socjalistycznym, w dużej mierze marksistowskim (acz w znaczeniu heterodoksyjnym), charakterze PPS. Otwarcie stwierdzano, że

Polskie stronnictwo socjalistyczne, jako stronnictwo mas pracujących, występując przeciwko wszelkim rządom klasowym, widzi jasno jak z rzeczywistości dzisiejszej zarysowuje się gmach gospodarki społecznej, opierający się na uspołecznieniu wszystkich narządzi i środków pracy oraz na społecznej organizacji wytwarzania ${ }^{6}$.

Z drugiej strony niemal równolegle potrzeba nowoczesności wyrosła na prawicy. W opozycji do rozwijającej się na gruncie krajowym opcji zachowawczej na bazie Ligi Polskiej, nawiązującej do TDP, uformował się organizacyjnie ruch narodowy. Roman Dmowski, jak polscy socja-

5 Program Paryski P.P.S., Warszawa I932, s. 5 n.

6 Program Paryski P.P.S., dz. cyt., s. 8. 
liści, szukał nowej treści dla politycznej organizacji narodu. Wbrew tradycji wielonarodowej Pierwszej Rzeczpospolitej, wbrew kosmopolitycznym tendencjom rozwijanym na gruncie niektórych nurtów socjalizmu, proponował rozumienie narodu już nie tylko jako kulturalną ciągłości pokoleń, ale przede wszystkim jako wspólnotę etniczną. Wiodącą rolę nie odgrywały tradycyjne warstwy przodkujące, ale wszyscy świadomi swojej narodowej odrębności i wynikających z niej obowiązków. Wbrew optyce socjalistów, dla których napięcia narodowe były pochodną konfliktów klasowych, Dmowski uznawał bezwzględną rywalizację narodów jako fakt kluczowy z punktu widzenia dalszego konstruowania założeń polskiej polityki. Pierwszorzędnymi celami Dmowskiego było: poszerzenie bazy narodowej przez wciągnięcie do pracy mas, którym interes narodowy mógł być przesłaniany przez eksponowane przez socjalistów interesy klasowe, następnie działania na rzecz ochrony i wzmacniania tkanki narodowej. Dlatego od początku istnienia polskiego ruchu narodowego komponent demokratyczny był jednym z filarów programu, stąd również Dmowski wyraźnie rozwijał orientację prorosyjską (najpierw w skali autonomicznej, następnie polityki zagranicznej) opierającą się na czynniku nie tyle słabszym czy geopolitycznie korzystniejszym, ale mniej niebezpiecznym dla bytu narodowego. $Z$ racji swojej niższości cywilizacyjnej, wedle Dmowskiego, możliwości asymilacyjne Rosjan względem Polaków były mocno ograniczone. Nawet dominacja polityczna nie musiała powodować bezpośredniego zagrożenia dla bytu narodowego. Inaczej sytuacja wyglądała ze strony narodu niemieckiego, który jako wyżej stojący w hierarchii, posiadał realne podstawy dla prowadzenia skutecznej germanizacji. Dmowski miał nacjonalistyczną perspektywę, dzięki której nabierał przekonania, że państwo można odbudować wcześniej czy później, ale powołanie do życia etnicznego narodu leży poza możliwościami bezpośrednich działań politycznych.

Warto jeszcze naszkicować jedną oś podziału poprzedzającą pojawienie się na scenie politycznej ruchów odwołujących się do mas. Przeniesienie centrum życia politycznego i utworzenie go na emigracji 
po powstaniu listopadowym było oznaką zdecydowanego prymatu, niezależnie od wewnętrznych sporów, postawy insurekcyjnej. Celem była restytucja Rzeczpospolitej. Dyskusja dotyczyła środków prowadzących do niepodległości. Postawa lojalistyczna, kluczowa dla drugiej połowy XIX wieku, była w powijakach. W latach 40. XIX wieku pojawiała się nieliczna, ale ważna konserwatywna grupa tzw. koterii petersburskiej’. Doświadczenie polityki rusyfikacyjnej w tzw. guberniach zabranych skłaniało autorów, takich jak Henryk Rzewuski czy Michał Grabowski, do powzięcia próby ugody. Przyjmowała ona różne oblicza. Michał Grabowski próbował poprzez polityczną lojalność wobec Romanowów uzyskać możliwość rozwoju społecznego i kulturalnego. Natomiast Henryk Rzewuski szedł o wiele dalej. W jego prowokacyjnych Mieszaninach obyczajowych można odnaleźć tezy o śmierci narodu i konieczności wtopienia się w wspólnotę Słowian pod przewodnictwem gwaranta porządku cara Mikołaja I ${ }^{8}$. Tragiczną próbę ugody i odbudowy tkanki narodowej za cenę lojalności podjął margrabia Aleksander Wielopolski.

Jednak dopiero burzliwe wydarzenia z I846 roku, a szczególnie I863 roku, doprowadziły do przeniesienia punktu ciężkości życia politycznego z emigracji do kraju. Klęska powstania styczniowego, głęboki zakres represji - godzących nie tyle w prawa polityczne, ile w byt narodowy - trauma klęski, wywołały potężną falę trójlojalizmu. W Warszawie wokół „Przeglądu Tygodniowego” powstało inteligenckie środowisko tzw. pozytywizmu warszawskiego. Program pozytywistów, nawiązujący w dużej mierze do ustaleń przedstawicieli liberalnego utylitaryzmu, wskazywał na inne cele niż niepodległość, a była nim modernizacja społeczeństwa polskiego. Pozytywiści poprzez taktykę propagowania tzw. pracy organicznej podkreślali konieczność budo-

7 R. Ludwikowski, Gtówne nurty w polskiej myśli politycznej, Warszawa I982, s. $35-4$ I.

8 Zob. szerz. H. Rzewuski, Wędrówki umystowe i mieszaniny obyczajowe, Kraków 20 Io. 
wy nowoczesnego społeczeństwa mieszczańskiego wedle liberalnych formuł popularnych na Zachodzie. Rozwój gospodarczy, silny stan mieszczański i działania na rzecz tolerancji i świeckiego modelu (nie tyle państwa, co przynajmniej edukacji), stanowiły credo pozytywistów. Walor materialny fundamentalnie został wzmocniony kosztem formalnego momentu odzyskania niepodległości. W Galicji podjęto podobny kierunek.

Trauma popowstańcza skutkowała wyłonieniem się tzw. krakowskiej szkoły historycznej. Historycy tacy jak Józef Szujski czy Walerian Kalinka podejmowali namysł nad przeszłością Polski i wskazywali na fundamentalne wady w konstrukcji Pierwszej Rzeczpospolitej jako na główną przyczynę upadku państwa. Krakowscy historycy radykalnie zerwali z historiografią „ofiary”, wskazując na konieczność pracy Polaków nad własnym stosunkiem do państwa. Tak ujęta perspektywa historyczna, stawiająca na jednej płaszczyźnie liberum veto i liberum conspiro, stanowiła silny fundament pod program polityczny autonomistów galicyjskich?. Program „stańczyków”, jak i pozytywistów, zakładał porzucenie sprawy polskiej w skali ponaddzielnicowej i koncentracje na sprawach dzielnicy. Kierunek autonomiczny i odrzucenie irredenty to jedyne i główne punkty styczne z „organicznikami” z Królestwa. W opozycji do modernizacyjnej wizji stawiano na rozwój organiczny, tj. wszystkich elementów istotowych tożsamości, a do tych zdecydowanie należała tradycja katolicka. Galicja była eksperymentem. Próbowano z jednej strony zobaczyć, czy możliwy jest autentyczny rozwój narodowy w ramach innego państwa; z drugiej zaś, chciano za pomocą pracy nad instytucjami autonomii wypracować w narodzie instynkt odpowiedzialności i szacunku do prawa i tym samym przyszłego państwa. W tej namiastce Polski, którą udało się stworzyć, w opozycji do tradycji polskiego życia politycznego, starano się uporać z problemami wyrastającymi poza perspektywę bieżącej polityki.

9 M. Jaskólski, Kaduceusz polski. Myśl polityczna konserwatystów krakowskich I866-I934, Kraków 2014, s. 43n. 
Znaczenie doświadczenia galicyjskich autonomistów dla odzyskania niepodległości, dla pierwszych lat odbudowy Polski, jest czymś poza wszelką dyskusją. Ostatnim epigonem polityki ugodowej był Dmowski, który już w nowych warunkach, stawiając sobie odmienne, powyżej opisane cele, podejmował taktyczną współpracę z caratem.

Ten zarys głównych linii sporu o Polskę w XIX wieku jest ważny i kluczowy dla zrozumienia charakteru debat narodowych w kolejnych dziesięcioleciach. W dwudziestoleciu międzywojennym, w warunkach już niepodległego państwa, dyskusja o treść wewnętrzną państwa i narodu była niezwykle rozwiniętą. Napięcie pomiędzy zagadnieniem tożsamości a wymogami modernizacji było kluczowe. Symboliczną figurą doby odzyskania niepodległości bezsprzecznie była postać Cezarego Baryki z Przedwiośnia Żeromskiego, który konfrontował mgliste marzenia doby zaborów z realnością odzyskanego państwa. Zmiana pokoleniowa, kluczowa również dla formacji intelektualnych XVIII wieku, w dwudziestoleciu odegrała ważną rolę. Syndrom "Baryki” (dawny wydaje się odpowiednik dzisiejszego syndromu „paryskiego") zdecydował o skłonności młodych, zazwyczaj urodzonych w okolicach roku ı9ıо, do radykalizmu. Dawne formacje zyskiwały uznanie młodszego pokolenia, o ile potrafiły przełamać wbudowany w parlamentaryzm komponent gadulstwa i przemawiać z pozycji faktów, inaczej z pozycji siły. Z tej perspektywy należy spoglądać na radykalizacje ruchu narodowego, popularność wśród młodych idei komunistycznych czy grawitację w kierunku nacjonalizmu części obozu sanacyjnego po śmierci Piłsudskiego.

Jednak to rok 1945 i powrót do warunków niewoli, w których wykuwały się schematy dziewiętnastowieczne, doprowadziły do pełnej restytucji palety dawnych orientacji. Łatwo dostrzeżemy ponowne napięcie pomiędzy emigracją a krajem, pomiędzy irredentą a ugodą, i kluczowe pęknięcie w obozie lewicy. Jednak w tym wypadku to nie opcja narodowa dominowała, ale wsparta z zewnątrz opcja kosmopolityczna, wykuwana uprzednio przez działaczy SDKPiL i KPP. Cześć konserwatystów, jak Aleksander Bocheński czy bracia Pruszyńscy, 
próbowali reaktywować prorosyjski program Wielopolskiego in pracy organicznej, z kolei narodowcy skupieni wokół PAX-u mogli wkomponować w nowy porządek swój tradycyjny antygermanizm. Spadkobiercy powstańców rozpoczęli równie heroiczny, jak i beznadziejny epizod walki zbrojnej.

Jednak bez nowych elementów życie umysłowe zamiera. Czasy komunizmu to okres nie tylko kontynuacji, ale również odmiennych poglądów i co za tym idzie, sporów. Dyskusja na temat kształtu polskiego katolicyzmu ma charakter o wiele szerszy niż analogiczne spory wcześniejsze. Obok tradycyjnej linii: opór a ugoda - rozwijał się oddolny ruch robotniczy, który swoje apogeum osiąną̧ w I980 roku. Wydaje się, że debata o własnej tożsamości jest wpisana nieodłącznie, nie tyle w naszą przeszłość, ale w sposób wspólnotowego bycia. Stąd uważne śledzenie polskich dyskusji, wychwytywanie elementów kontynuacji i nowości, ma fundamentalne znaczenie dla teraźniejszości. Trzeba pamiętać, że spór w ramach wspólnoty może mieć różne oblicza, może ubogacać, ale też osłabiać strukturę. Studia nad polskim dziedzictwem, kraju liberum veta, mają wciąż esencjalne znaczenie dla polityki narodowej.

\section{Streszczenie}

POLSKA, ALE JAKA?

Artykuł w sposób syntetyczny wprowadza w zagadnienie najważniejszych dyskusji prowadzonych odnośnie kształtu Rzeczpospolitej doby porozbiorowej. Doświadczenie utraty własnej państwowości fundamentowanie zdeterminowało kształt polskiej myśli politycznej. Oprócz sporów w materialnym wymiarze idei kształtu wspólnoty politycznej charakterystycznych na podziału na osi prawica - lewica, prowadzona była również dyskusja odnośnie w zakresie sposoby odzyskania niepodległości. Napięcie pomiędzy obozem insurekcyjnym a tzw. ugodowym tworzyło jedną z głównych linii podziału politycz- 
nego w Polsce ostatnich 200 lat. Poprzez zrekonstruowane głównych osi politycznych debat Polaków doby porozbiorowej i ich genezy autor pragnie naświetlić główne punkt orientacyjne, które towarzyszą nam do dziś dnia.

\section{Summary}

POLAND, BUT WHAT?

The article introduces to the most important political debates in Poland in the post-partition era. Experience of losing own state and long period of living under foregin goverment fundamantaly determined ways of political thinking in Poland. That's why besieds disputes over the rules of political and social order, Poles were in debates over the ways of restitution of independet state. Lasted almost 200 years discution between insurectionists and political realism fallowers was one of the most significant character of intelectuall history of Poland. The presented sketch has shown that the polish political thinking today is still deeply determined by old divisions.

\section{Bibliografia}

Głębocki H., „Diabet Asmodeusz” w niebieskich binoklach i kraj przysztości: Hr. Adam Gurowski i Rosja, Kraków 2012 (Arkana Historii). Jaskólski M., Kaduceusz polski. Myśl polityczna konserwatystów krakowskich 1866-1934, Kraków 2014.

Król M., Konserwatyści i niepodlegtość. Studia nad polską myślą konserwatywna, Warszawa 1985.

Ludwikowski R., Gtówne nurty polskiej myśli politycznej I8I5-I89o, Warszawa 1982.

Ślisz H., Henryk Rzewuski. Życie i poglady, Warszawa 1986. 
Rysiewicz M., Monarchia - lud - religia. Monarchizm konserwatywnych środowisk politycznych Wielkiej Emigracji w latach I83I-I848, Kraków 2015.

Rzewuski H., Wędrówki umystowe i mieszaniny obyczajowe, Kraków 2010.

Węgrzyn I., Henryk Rzewuski wobec Rosji i idei stowiańskiej, w: Między realizmem a apostazja narodowa. Koncepcje prorosyjskie w polskiej myśli politycznej, red. M. Zakrzewski, Kraków 2015. 